\title{
E-COMMERCE BUSINESS TO CONSUMERS SARANA BELANJA AMAN, NYAMAN DAN EFISIEN
}

\author{
Santoso $^{1}$, Wan Mariatul Kifti ${ }^{2}$, Elly Rahayu ${ }^{3}$ \\ ${ }^{1,2,3)}$ Program Studi Sistem Informasi STMIK Royal Kisaran \\ e-mail: ellyrahayu68@gmail.com
}

\begin{abstract}
Abstrak
Pengabdian Kepada Masyarakat adalah suatu kegiatan yang bertujuan membantu masyarakat tertentu dalam beberapa aktivitas tanpa mengharapkan imbalan dalam bentuk apapun. Secara umum program ini dirancang oleh perguruan tinggi yang ada di Indonesia untuk memberikan kontribusi nyata bagi bangsa Indonesia, khususnya dalam mengembangkan kesejahteraan dan kemajuan bangsa Indonesia. Maksud dari kegiatan pengabdian ini adalah melaksanakan Tri Dharma Perguruan Tinggi berupa Pengabdian Kepada Masyarakat sebagai pengamalan ilmu pengetahuan dan teknologi kepada siswa/i SMK Negeri 1 Kisaran serta memberi pemahaman kepada siswa/I SMK Negeri 1 Kisaran tentang e-commerce, sarana belanja dan menjual secara online , aman, nyaman, dan efisien. Kegiatan ini diharapkan dapat menjadi motivasi siswa/i untuk dapat mengenal dan memanfaatkan e-commerce untuk berdagang dan berbelanja secara online . Bentuk kegiatan dilakukan dengan penyampaian materi dalam bentuk presentasi dan praktek sehingga peserta dapat mencoba langsung untuk melakukan pemesanan suatu produk pada penyedia layanan belanja online. Hasilnya adalah Siswa SMK Negeri 1 Kisaran tidak hanya memahami bagaimana belanja secara online tetapi juga mengetahui jenis-jenis e-commerce, serta potensi keuntungan yang diperoleh dengan pemanfaatan e-commerce sebagai sarana berdagang di era digitalisasi.
\end{abstract}

Kata kunci: e-commerce, digitalisasi, belanja online, Pengabdian Masyarakat

\begin{abstract}
Community Service is an activity that aims to help certain communities in some activities without expecting anything in return. In general, this program is designed by universities in Indonesia to make a real contribution to the Indonesian people, especially in developing the welfare and progress of the Indonesian nation. The purpose of this dedication activity is to carry out the Tri Dharma of Higher Education in the form of Community Service as a practice of science and technology to students of SMK Negeri 1 Kisaran and to give understanding to students of SMK Negeri 1 Kisaran about e-commerce, shopping and selling facilities online, safe, comfortable and efficient. This activity is expected to be a motivation for students to get to know and use ecommerce to trade and shop online. The form of activities is carried out by delivering material in the form of presentations and practices so that participants can try directly to place an order for a product at an online shopping service provider. The result is that the students of SMK Negeri 1 Kisaran not only understand how to shop online but also know the types of e-commerce, as well as the potential benefits gained by using e-commerce as a means of trading in the digitalization era.
\end{abstract}

Keywords: e-commerce, digitalization, online shopping, Community Service

\section{PENDAHULUAN}

Pengabdian Kepada Masyarakat adalah suatu kegiatan yang bertujuan membantu masyarakat tertentu dalam beberapa aktivitas tanpa mengharapkan imbalan dalam bentuk apapun. Secara umum program ini dirancang oleh perguruan tinggi yang ada di Indonesia untuk memberikan kontribusi nyata bagi bangsa Indonesia, khususnya dalam mengembangkan kesejahteraan dan 
kemajuan bangsa Indonesia. Kegiatan PengabdianKepada Masyarakat merupakan salah satu bagian dari Tri Dharma Perguruan Tinggi.

Tema yang diangkat dalam pengabdian pada siswa/i SMK Negeri 1 Kisaran adalah ecommer. Masyarakat Indonesia sangat terkenal dengan perilaku konsumtifnya. Hal ini dikarenakan populasi masyarakat yang terus bertambah, keinginan yang beraneka ragam dan daya belinya juga semakin meningkat. Seiring dengan perkembangan teknologi dan informasi, semakin mudah untuk melakukan semua aktifitas, apalagi dalam berbelanja bisa dilakukan secara online. Hasil penelitian sebuah lembaga pada tahun 2018 yang dikutip oleh Widowati (Widowati, 2019) mengatakan bahwa Indonesia menjadi salah satu negara di dunia yang tingkat pertumbuhan e-commerce nya tercepat di dunia. Pengguna internet pertumbuhan penduduk indonesia menjadi faktor yang mendorong perkembangan e-commerce di Indonesia. Prilaku konsumtif masyarakat Indonesia merupakan peluang potensial bagi dunia usaha di era digitalisasi.

E-commerce dijadikan tema pengabdian masyarakat di kalangan siswa-siswi SMK Negeri I Kisaran karena manfaat dari e-commerce yang dapat membuat setiap individu Melalui ecommerce, setiap pribadi memiliki kesempatan dan peluang yang sama untuk berhasil dan bersaing dalam dunia bisnis di dunia maya (Aco \& Endang, 2017) tak terkecuali pelajar, karena mayoritas pelajar saat ini menggunakan android sebagai sarana komunikasi. Bagi individu keberadaan ecommerce bisa mendatangkan pendapatan baru dan bagi dunia usaha, tidak hanya memperluas pangsa pasar tetapi juga bisa meminimalkan biaya operasional dan meminimalkan human eror serta mempercepat waktu proses (Maulana et al., 2015)

Electronic Commerce (E-Commerce) merupakan transaksi bisnis yang dilakukan dengan bantuan internet. Electronic Commerce (E-Commerce) adalah aktivitas penyebaran, penjualan, pembelian, pemasaran produk (barang dan jasa), dengan memanfaatkan jaringan telekomunikasi seperti internet dan jaringan komputer (Santoso, 2015)

E-commerce telah merubah pola belanja konsumen dari konvensial menjadi online. Ini tentunya menjadi peluang bagi setiap orang, karena bisnis di era digital saat ini tidak lagi berbayas ruang dan waktu. Aktivitas penyebaran, penjualan, pembelian, pemasaran produk (barang dan jasa), dengan memanfaatkan jaringan telekomunikasi seperti internet dan jaringan komputer munculnya Lazada, Zalora, Blibli, dan lainnya merupakan bukti pergeseran pola belanja masyarakat menjadi lebih effisien, aman dan nyaman dengan fasilitas e-commerce yang tersedia.

Maksud dari kegiatan pengabdian ini adalah melaksanakan Tri Dharma Perguruan Tinggi berupa Pengabdian Kepada Masyarakat sebagai pengamalan ilmu pengetahuan dan teknologi kepada SMK Negeri 1 Kisaran oleh Dosen STMIK Royal Kisaran. Tujuan yang ingin dicapai dalam kegiatan pengabdian kepada masyarakat ini adalah memberi pemahaman kepada siswa/I SMK Negeri 1 Kisaran tentang e-commerce sebagai sarana belanja secara online aman, nyaman, dan efisien.

\section{METODE}

Langkah pertama yang dilakukan sebelum dilaksanakannya kegiatan pengabdian ini adalah melakukan identifikasi masalah. Apa persoalan yang sedang dihadapi siswa-siswi SMK Negeri I Kisaran . Hasil identifikasi adalah perlu ditingkatkan kembali pengetahuan, dan wawasan siswa tentang e-commerce. Peserta pengabdian ini adalah siswa-siswa SMK Negeri I Kisaran kelas XII yang berjumlah 38 orang. Dari identifikasi masalah yang dilakukan kemudian dirancang metode yang dipilih untuk memberikan pemahaman kepada peserta. Metode yang digunakan adalah metode ceramah, diskusi, dan simulasi. Metode ceramah merupakan metode lisan yang diberikan langsung kepada peserta. Metode ceramah ini diberikan dengan bantuan slide power point sehingga lebih mudah memberikan pehamanan kepada peserta karena umumnya pelajar lebih menyukai simbol atau animasi yang membuat suasana tidak membosankan. Peserta juga diberikan kesempatan untuk mengajukan pertanyaan atau berbagi pengalaman dalam sesi diskusi. Dan simulasi digunakan kepada peserta untuk mempraktekkan langsung memilih salah satu sarana ecommerce yang tersedia di indonesia dan mencoba untuk melakukan transaksi bisnis. 


\section{HASIL DAN PEMBAHASAN}

Kegiatan pegabdian kepada masyrakat dilaksanakan pada tanggal 13 November 2019, pukul $08.00 \mathrm{wib}$ s/d selesai. Kegiatan pengabdian kepada masyarakat ini dilakukan oleh tim Dosen STMIK Royal Kisaran yang berjumlah 3 orang dan 2 orang mahasiswa. Metode pelaksaan dalam pengabdian masyarakat ini yaitu presentasi penyampaian materi. Penguraian materi dimulai dari pengenalan internet, pengenalan e-commerce, pengenalan business to consumers dan cara dapat berbelanja secara online dengan aman, nyaman, dan efisien. Berikut materi yang diberikan diantaranya adalah Pengenalan e-commerce, Konsep B2C dan C2C, Tips dan cara belanja online, serta simulasi . Jumlah peserta 38 orang khusus pelajar kelas XII .

Tabel 1.1 Materi E-Commerce

\begin{tabular}{l|l}
\hline Kegiatan & Oleh \\
\hline Pengenalan E-Commerce & Elly Rahayu, SE., MM \\
\hline Konsep B2C dan C2C & Wan Mariatul Kifti, SE., MM \\
\hline Tips dan Cara Belanja Online & Santoso, SE., MM \\
Simulasi & Tim Narasumber \\
\hline
\end{tabular}

Pengenalan e-commerce bagi pelajar penting dilakukan karena masih banyak opini masyarakat kita bahwa perdagangan melalui e-commerce tidak aman dan mahal hal ini diungkapkan dalam penelitian Firmansyah yang menyatakan salah satu kendala non teknis implementasi e-commerce bahwa e-commerce tidak aman dan mahal. (Firmansyah, 2018) Melalui materi ini, diharapkan peserta dapat memiliki pemahaman yang berbeda, baahwa peluang bisnis dengan sarana e-commerce. Pada materi ini dipaparkan tentang perkembangan e-commerce di Indonesia, bentuk, jenis serta beberapa pelajar dan mahasiswa yang sukses dalam memanfaatkan ecommerce.

Materi lainnya tentang Business to Customer, juga dipresentasekan narasumber kepada peserta. Materi ini penting. Pada penelitian firmansyah dinyatakan bahwa jumlah transaksi ecommerce Indonesia dengan tipe transaksi Business to Customer (B2C) terus mengalami peningkatan (Firmansyah, 2018). Materi ini akan meningkatkan pengetahuan pelajar tentang tipe tipe transaksi yang banyak dilakukan di Indonesia e-commerce.
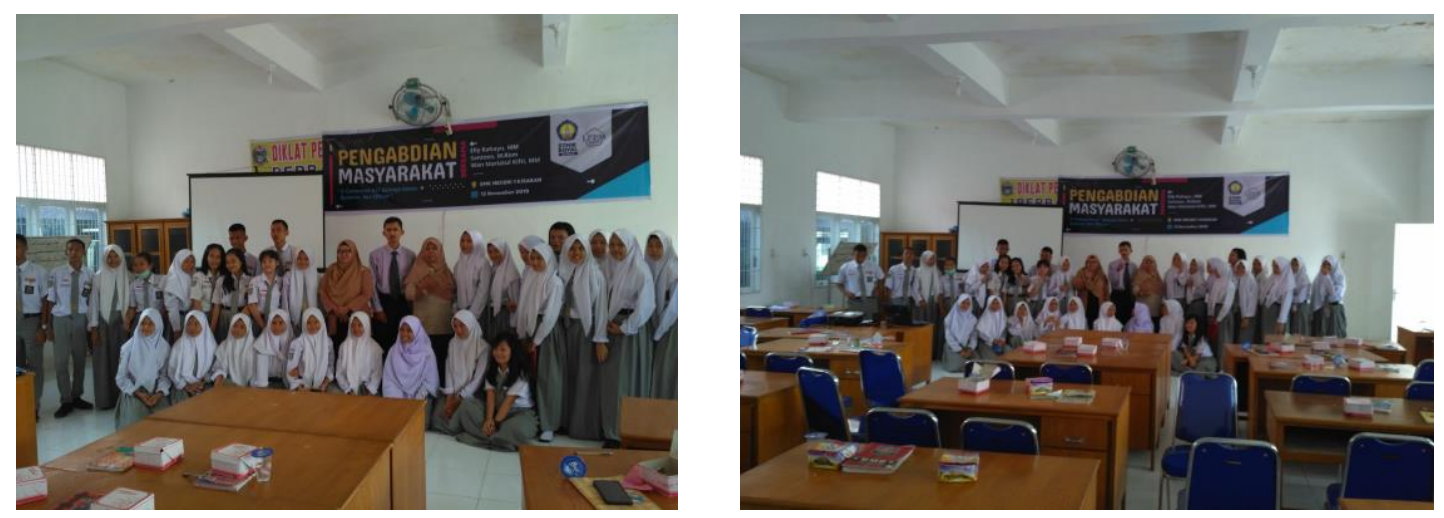

\section{Gambar 1. Peserta dan Tim Narasumber}

Tips dan cara belanja online merupakan sub materi yang juga dipaparkan kepada peserta. Harapannya melalui materi ini bisa merubaha pola pikir masyarakat terutama generasi milenial bahwa belanja online aman, nyaman dan tidak mahal. Perubahan opini ini akan menjadi pasar potensial bagi para usahan di era digital. Tujuan akhirnya adalah perubahan pola pikir dari konvensional ke digitalisasi.. 


\section{SIMPULAN}

Berbagai materi yang dipaparkan kepada peserta yaitu siswa SMK Negeri I Kisaran mampu membuka pengetahuan dan wawasan siswa tentang e-commerce. Tujuan yang ingin dicapai dalam kegiatan pengabdian kepada masyarakat ini yaitu memberi pemahaman kepada siswa/I SMK Negeri 1 Kisaran tentang e-commerce sebagai sarana belanja secara online aman, nyaman, dan efisien tercapai dengan baik. Beberapa alasan mengapa materi tentang ini diberikan juga dapat difahami dengan baik, hal ini terlihat dari partisipasi dan antusias peserta mengajukan berbagai pertanyaan terkait tema pengabdian.Metode simulasi yang diberikan juga menambah pengetahuan peserta tentang implementasi e-commerce bagi dunia usaha di Indonesia.

\section{SARAN}

Tidak ada pelaksanaan kegiatan yang benar-benar sempurna tanpa kekurangan, Tidak terkecuali kegiatan pengabdian ini. Adanya keterbatasan waktu, pendanaan dan sarana serta metode yang digunakan menyebabkan kegiatan ini berjalan, namun masih membutuhkan saran dan masukan bagi perbaikan dikemudian hari. Disarankan bagi kegiatan pengabdian masyarakat selanjutnya untuk membahas tentang e-commerce lebih mendalam terutama manfaat dan potensinya yang sangat besar bagi keuntungan dunia usaha sehingga benar-benar mampu memotivasi para pelajar kelak tidak memiliki pola pikir hanya sebagai pencari kerja namun sebagai pencipta usaha yang bisa lebih bermanfaat bagi banyak orang.

\section{UCAPAN TERIMA KASIH}

Ucapan terima kasih tak terhingga kepada semua pihak yang telah banyak membantu dari mulai perencanaan sampai pelaporan kegiatan, Kepada:

1. Ketua STMIK Royal, memberikan fasilitas serta izin untuk melakukan kegiatan pengabdian masyarakat

2. Ketua LPPM STMIK Royal yang telah memberikan dukungan moril serta sarana yang digunakan dalam kegiatan pengabdian ini

3. Kepada Kepala Sekolah, Wakil Kepala Sekolah, guru dan staff SMK Negeri I Kisaran yang sudah memfasilitasi, memberikan dukungan yang luar biasa kepada Tim dosen STMIK Royal

4. Seluruh pihak-pihak lain yang terlibat baik secara langsung maupun tidak langsung

\section{DAFTAR PUSTAKA}

Aco, A., \& Endang, A. H. (2017). Analisis Bisnis E-Commerce pada Mahasiswa Universitas Islam Negeri Alauddin Makassar. Jurnal Insypro, 2, 1-13.

Firmansyah, A. (2018). KAJIAN KENDALA IMPLEMENTASI E-COMMERCE DI INDONESIA. Masyarakat Telematika Dan Informasi: Jurnal Penelitian Teknologi Informasi Dan Komunikasi, 8(2). https://doi.org/10.17933/mti.v8i2.107

Maulana, S. M., Susilo, H., \& Riyadi. (2015). Implementasi E-Commerce Sebagai Media Penjualan Online. Jurnal Administrasi Bisnis, 29(1), 1-9.

Santoso. (2015). E-Marketing Pada Ukm Sepatu Bunut Abang Adik Kisaran. Jurteksi, 2(179), 8791.

Widowati, H. (2019). Indonesia Jadi Negara dengan Pertumbuhan E-Commerce Tercepat di Dunia. Katadata.Co.Id. 